\title{
Impulse Turbine with Self-pitch-controlled Guide Vanes for Wave Power Conversion (Effect of Guide Vane Geometry on the Performance)
}

\author{
M. TAKAO*, Y. KINOUE, T. SETOGUCHI, T. OBAYASHI and K. KANEKO \\ Department of Mechanical Engineering, Saga University, 1 Honjo-machi, Saga-shi, Saga, 840-8502, Japan
}

(Received in final form 23 February 1999)

\begin{abstract}
An impulse turbine with self-pitch-controlled guide vanes has been developed specially for wave energy conversion by the authors. Based on that work, a large turbine of $1 \mathbf{m}$ diameter has been fabricated and operated on the west coast of India. In a practical turbine system, the guide vanes need substantial supports in order to heighten the strength. Such supports affect the performance of the turbine. In this paper, the etfect of guide vane support geometry on starting and running characteristics of the turbine was investigated experimentally. Two types of cross sections of support were studied, that is, circular type and airfoil type. The effect of support length was also studied.
\end{abstract}

Keywords: Fluid machinery, Impulse turbine, Guide vane, Natural energy, Ocean energy, Wave power generator.

\section{INTRODUCTION}

The Wells turbine is a self-rectifying air turbine which is expected to be widely used in wave energy devices with oscillating water-air column. Several reports describe the performance of the Wells turbine both at starting and running conditions (Inoue et al., 1986; Kaneko et al., 1986; Raghunathan and Tan, 1982; Sarmento et al., 1987; Setoguchi et al., 1990). According to these results, the Wells turbine has inherent disadvantages, that is, lower efficiency, poorer starting and higher noise level in comparison with conventional turbines.
In order to overcome these weak points, an impulse turbine with self-pitch-controlled guide vanes for wave energy conversion has been developed by Setoguchi et al. (1996). That turbine system has guide vanes before and behind the rotor so as to operate efficiently in a reciprocating air flow. The guide vanes rotate around the pivots by the aerodynamic moment induced by the reciprocating air flow. For the turbine, verification on the west coast of India by NIOT indicates that the efficiency is superior to that of the Wells turbine (Santhakumar et al., 1998). In a practical turbine system, the guide vane should be equipped with a

* Corresponding author. Tel.: +81-952-28-8605. Fax: +81-952-28-8587. E-mail: takao@ shinden.me.saga-u.ac.jp. 
thick support in order to heighten the strength. However, the effect of guide vane with the support on the performance has not been clarified so far.

The objective of this paper is to clarify the effect of guide vane geometry on the performance of the impulse turbine with self-pitch-controlled guide vanes. In the experiments, the effects of thickness, length and cross sectional shape of support on the starting and running characteristics have been clarified by the use of turbine test equipment under sinusoidally reciprocating flow conditions and steady flow conditions.

\section{EXPERIMENTAL APPARATUS AND PROCEDURE}

Figure 1 shows a schematic view of the impulse turbine with self-pitch-controlled guide vanes. Its design objective is that the turbine can be operated by the reciprocating air flow generated by an oscillating water column type of wave power generator. The turbine blades are symmetrical with

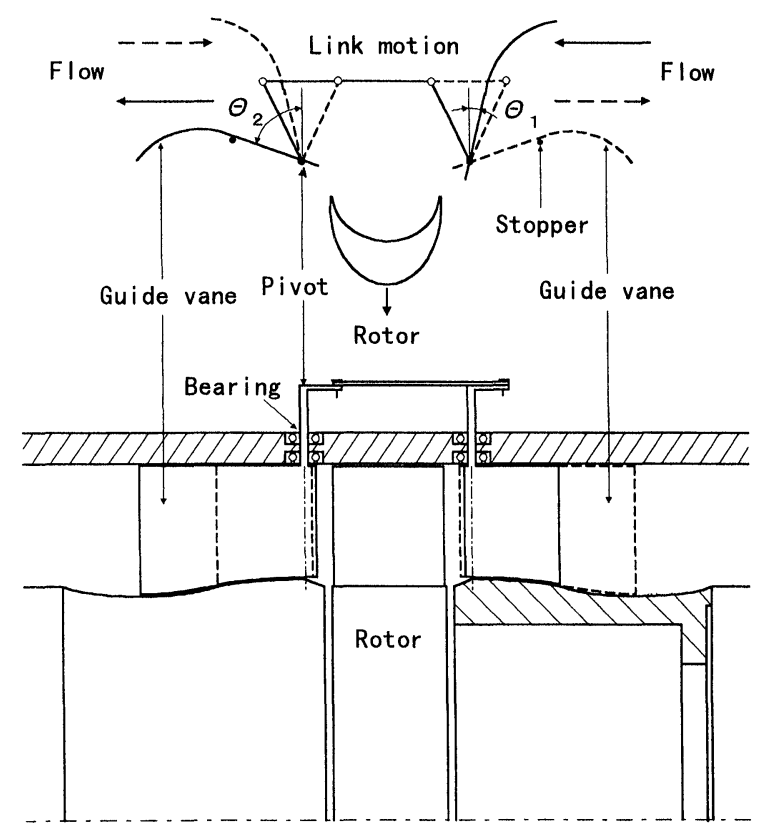

FIGURE 1 Outline of impulse turbine with self-pitchcontrolled guide vanes respect to the plane of rotation (zero reaction). There are two rows of guide vanes which are free to rotate on either side of the turbine. However, each pair of opposite vanes are linked together as shown in Fig. 1 such that they are constrained to rotate together. When the direction of air flow is shown by thick arrows in Fig. 1, any pairs of guide vanes are supposed that the orientation of them are shown by thick lines. When air flows reversibly, the vanes rotate and take up the orientations shown in dashed lines by the action of aerodynamic moments. Mechanical stops ensure that the vanes rotate between two pre-set angles. The hub under the vanes is spherical so that the clearance between the hub and inner edge of the vane is constant. Depending on the direction of flow, the upstream vanes are regarded as nozzle setting and the downstream vanes as diffuser setting and so the turbine works efficiently whatever may be the direction of flow.

The impulse turbine was tested in a test-rig which was capable of generating reciprocating air flow. The test-rig consists of a large piston and cylinder, a settling chamber and a 300-mm-diameter test section with a bell-mouth entry and exit as shown in Fig. 2. The details may be found in Setoguchi

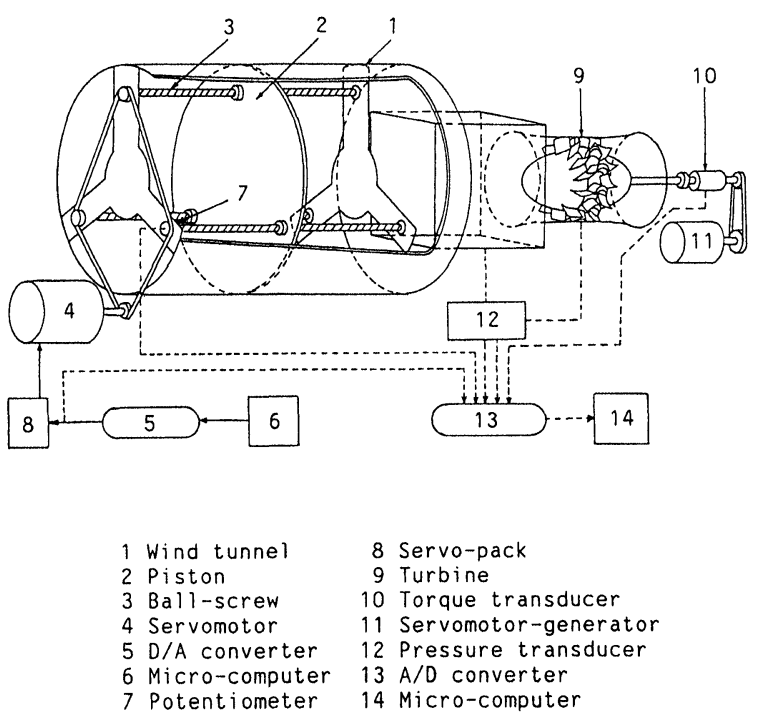

FIGURE 2 Test apparatus. 
et al. (1991). The piston is moved by a computer controlled servo-motor through three ball screws. The turbine was placed at the center of the test section and tested at a constant rotational speed under steady flow conditions and sinusoidal flow condition $(f=0.1 \mathrm{~Hz})$. The flow rate was measured by Pitot tube survey. The overall performance was evaluated from the turbine output power, namely torque $T$ and rotational speed $\omega$ and the pneumatic power input to the turbine, namely the flow rate $Q$ and total pressure drop between settling chamber and atmosphere $\Delta p$. Tests were performed with $\Delta p$ in the range of $200-2500 \mathrm{~Pa}, \omega$ up to $370 \mathrm{rad} / \mathrm{s}$ and $Q$ up to $0.32 \mathrm{~m}^{3} / \mathrm{s}$. The Reynolds number based on blade chord was $6.1 \times 10^{4}$ at maximum efficiency point. The uncertainty in turbine efficiency was about $\pm 2 \%$.

Different vane support geometries were tested. Tests were conducted for different support lengths $L$ (see Fig. 3(a)). The guide vanes flip between $\theta_{1}=17^{\circ}$ and $\theta_{2}=72.5^{\circ}$ as shown in Fig. 3(a) $\left(\theta_{1}\right.$ : nozzle setting angle, $\theta_{2}$ : diffuser setting angle). The guide vane geometries tested are shown in

(a)

(a) Guide vane

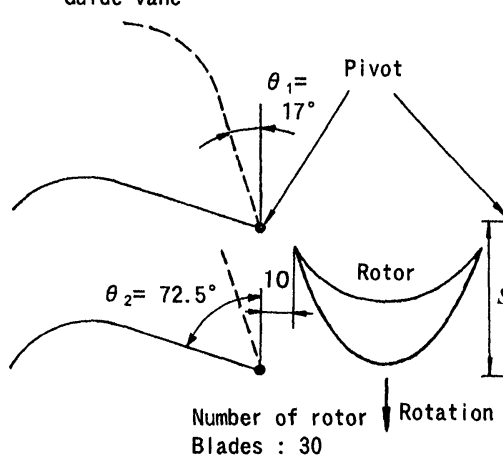

$H=40 \mathrm{~mm}$

$L=13.3,26.7,40 \mathrm{~mm}$

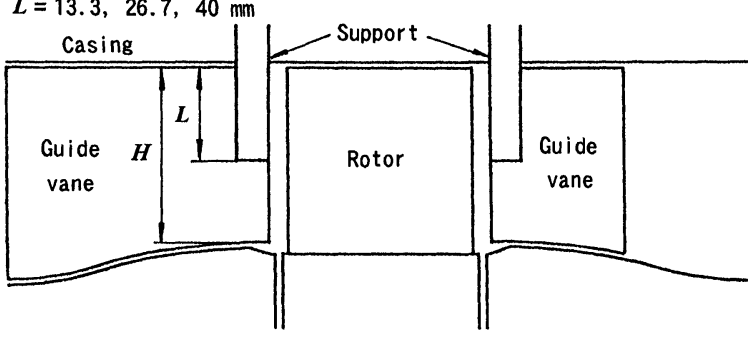

(b)
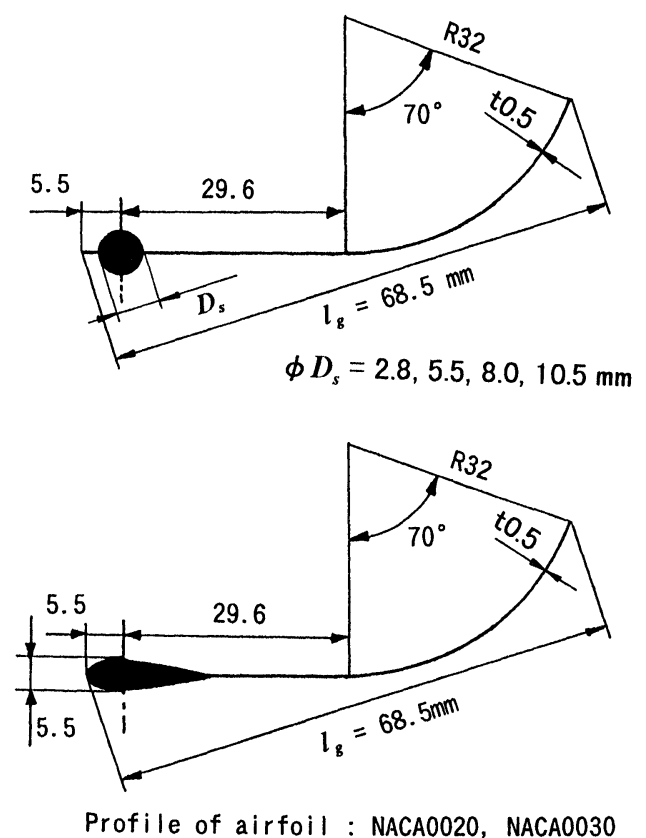

(c)

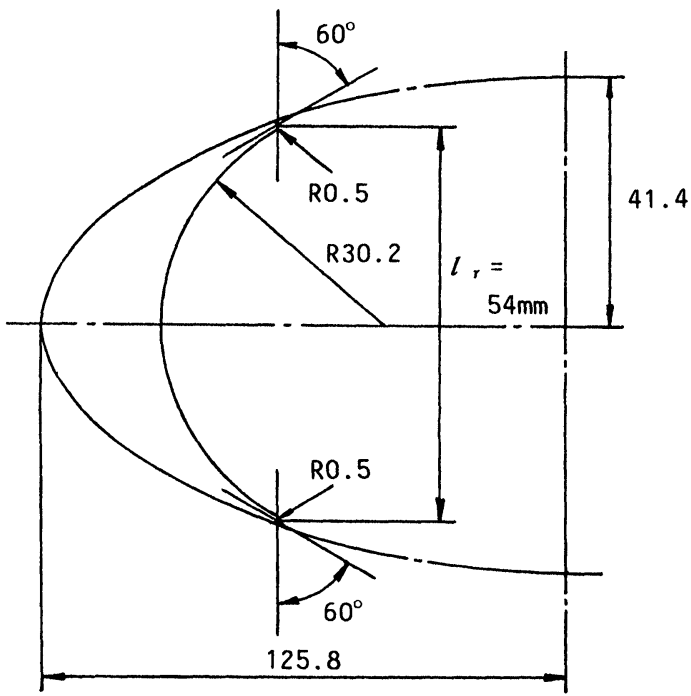

FIGURE 3 Turbine geometry. (a) Turbine configuration, (b) guide vane geometry, (c) outline of rotor blade. 
Fig. 3(b). The guide vane consists of a straight line and a circular-arc with a camber angle of $70^{\circ}$. The chord length $l_{\mathrm{g}}$ is $68.5 \mathrm{~mm}$ and the gap between vanes $S_{\mathrm{g}}$ is $30.8 \mathrm{~mm}$ giving space-to-chord ratio of 0.45 . Four diameters of circular cross section of support $D_{\mathrm{s}}(2.8,5.5,8.0$ and $10.5 \mathrm{~mm})$ were tested. Supports having two airfoil sections (NACA0020 and NACA0030) were also tested. The maximum thickness in both cases is $5.5 \mathrm{~mm}$. The vane thickness is $0.5 \mathrm{~mm}$ in all cases.

Figure 3(c) shows the outline of rotor blade. The detailed information on the rotor used in the experiments is as follows. The rotor blade profile: circular-arc for pressure side and ellipse for suction side, blade inlet (or outlet) angle: $60^{\circ}$, outer diameter $298 \mathrm{~mm}$, blade thickness: $30 \%$, blade chord $l: 54 \mathrm{~mm}$, space-to-chord ratio: 0.5 , and tip clearance: $1 \mathrm{~mm}$. Number of blade $z$ is 30 . Blade height $b$ is $44 \mathrm{~mm}$. The rotor hub-to-tip ratio is 0.7 . Sweep angle is $7.5^{\circ}$.

\section{EXPERIMENTAL RESULTS AND DISCUSSIONS}

\section{Running Characteristics}

The effect of guide vane geometry on the running characteristics under sinusoidally oscillating flow conditions is evaluated by the relationship between mean efficiency $\bar{\eta}$ and flow coefficient $\Phi$ defined as:

$$
\begin{gathered}
\bar{\eta}=\left(f \int_{0}^{1 / f} T \omega \mathrm{dt}\right) /\left(f \int_{0}^{1 / f} \Delta p Q \mathrm{dt}\right) \\
\Phi=V_{\mathrm{a}} / U_{\mathrm{R}}
\end{gathered}
$$

where $t$ : time, $V_{\mathrm{a}}$ : maximum value of mean axial velocity $v_{\mathrm{a}}, U_{\mathrm{R}}$ : circumferential velocity at mean radius $r_{\mathrm{R}}$.

The effect of the support diameter on mean efficiency is shown in Fig. 4. The case of sharp edge (this corresponds to the case without supports) is denoted by the dotted line for comparison. The

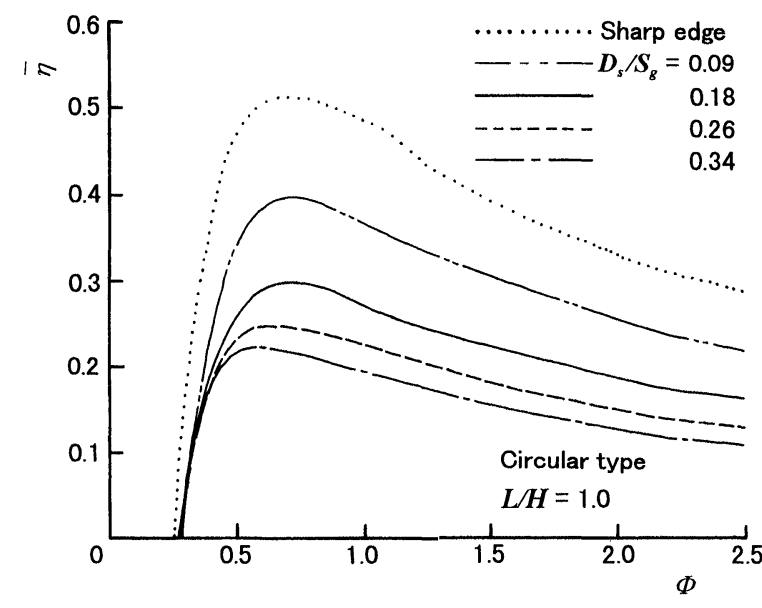

FIGURE 4 Effect of support diameter on mean efficiency (circular type).

figure shows that the turbine efficiency is rather deteriorated by equipping the supports. Furthermore, it is found that the efficiency for the case with supports decreases with the increase of $D_{\mathrm{s}} / S_{\mathrm{g}}$ in a whole range of $\Phi$. Now let us consider the above reasons on the basis of experimental results obtained under steady flow conditions.

The torque coefficient $C_{\mathrm{T}}$, input coefficient $C_{\mathrm{A}}$ and flow coefficient $\phi$ of the turbine rotor are defined as:

$$
\begin{aligned}
C_{\mathrm{T}} & =T /\left\{\rho\left(v_{\mathrm{a}}^{2}+U_{\mathrm{R}}^{2}\right) b l z r_{\mathrm{R}} / 2\right\}, \\
C_{\mathrm{A}} & =\Delta p Q /\left\{\rho\left(v_{\mathrm{a}}^{2}+U_{\mathrm{R}}^{2}\right) b l z v_{\mathrm{a}} / 2\right\}, \\
\phi & =v_{\mathrm{a}} / U_{\mathrm{R}},
\end{aligned}
$$

where $\rho$ is density of air.

Figure 5 shows the effect of the diameter of support on turbine characteristics under steady flow condition. As is evident from Fig. 5(a), the values of $C_{\mathrm{T}}$ for the case with supports for any $D_{\mathrm{s}} / S_{\mathrm{g}}$ are about the same in comparison with case of sharp edge, though the value increases slightly with the increase of $D_{\mathrm{s}} / S_{\mathrm{g}}$. On the other hand, it is clear from Fig. 5(b) that $C_{\mathrm{A}}$ increases by equipping the supports, and the value increases with the increase of $D_{\mathrm{s}} / S_{\mathrm{g}}$. Therefore, the effect of the diameter of support shown in Fig. 5 is due to 
(a)

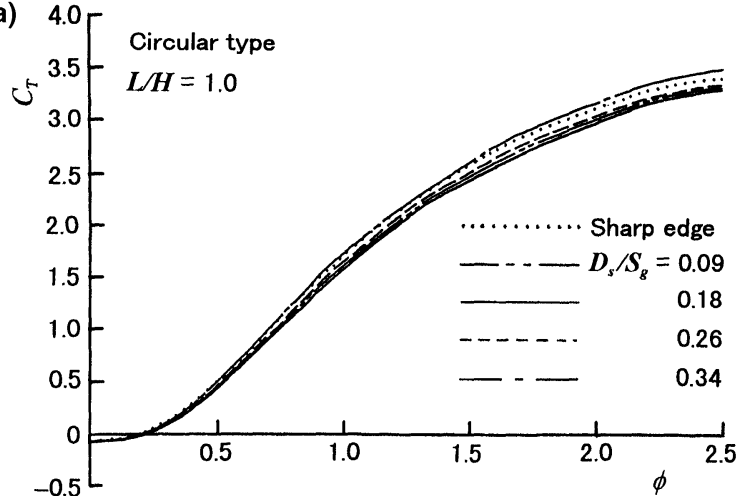

(b)

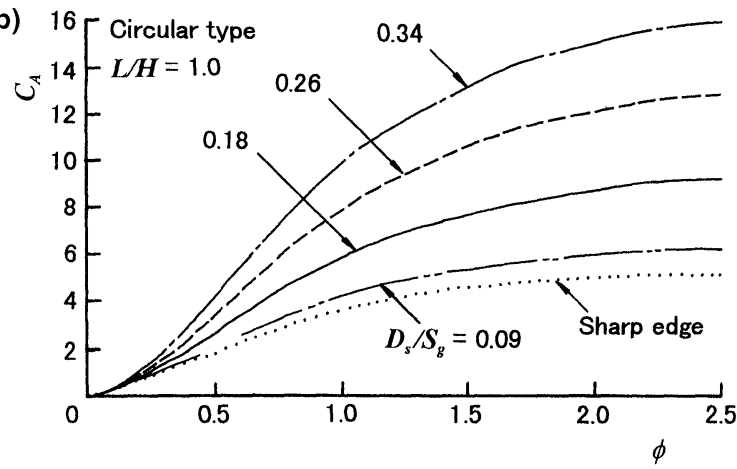

FIGURE 5 Effect of support diameter on turbine characteristics under steady flow condition (circular type). (a) Torque coefficient, (b) input coefficient.

the increase in $\Delta p$ because the efficiency under steady flow condition is estimated by

$$
\eta=T \omega /(\Delta p Q)=C_{\mathrm{T}} /\left(C_{\mathrm{A}} \phi\right) .
$$

The reason is considered that the separation occurs on the support of upstream guide vane, though, for the support of downstream guide vane, the shape with radius of curvature is preferable to sharp edge.

For support diameter to vane pitch ratio $D_{\mathrm{s}} / S_{\mathrm{g}}$ $=0.18$, tests were done for different support lengths $L / H=0.33,0.67$ and 1.0. Figure 6 shows the effect of the support length on mean efficiency. The efficiency decreases with the increase of $L / H$ in a whole range of $\Phi$. This result is because the input coefficient $C_{\mathrm{A}}$ increases with the increase of $L / H$ (Fig. 7(b)) as the torque coefficient is almost the same for any $L / H$ (Fig. 7(a)).

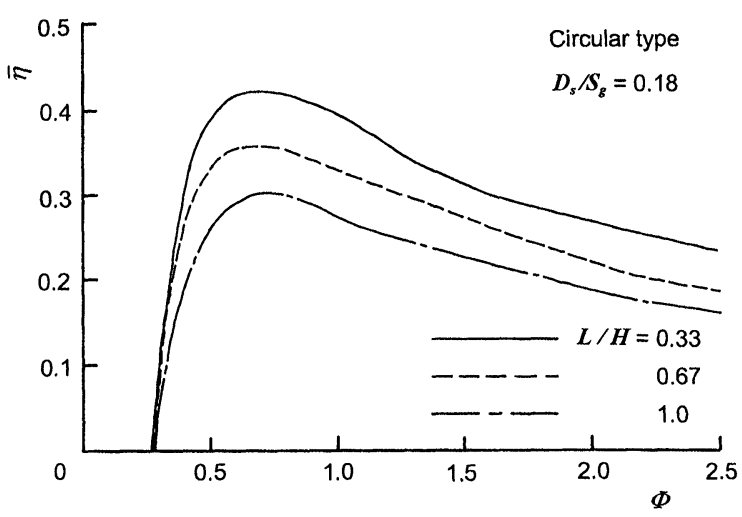

FIGURE 6 Effect of support length on mean efficiency (circular type).
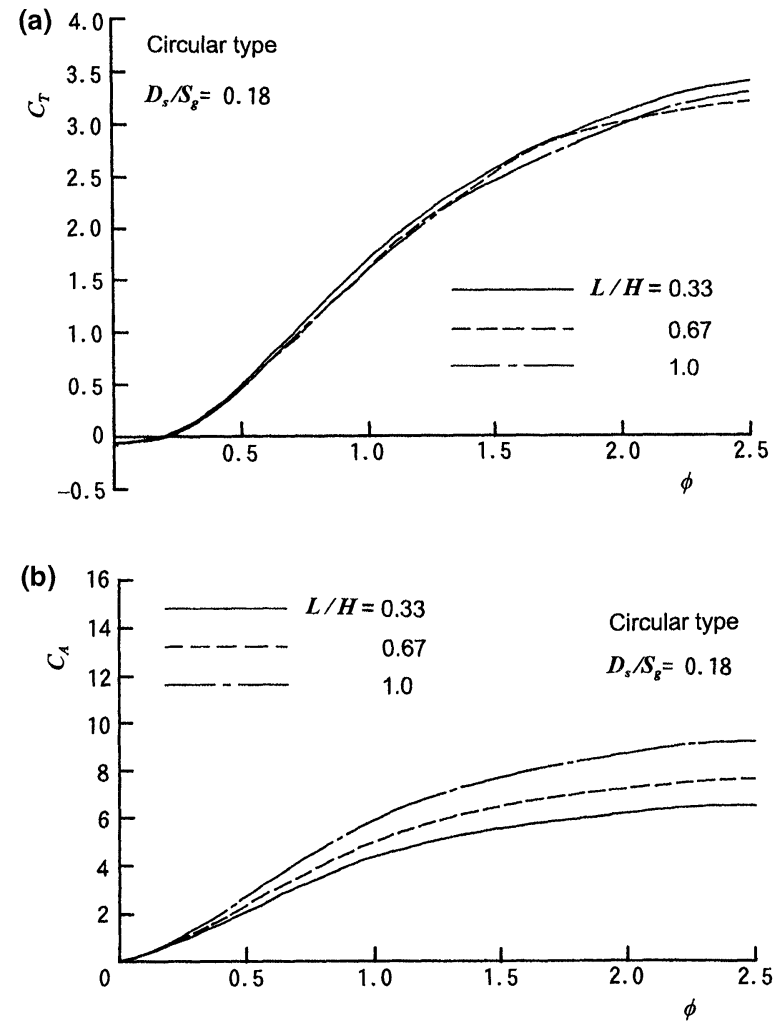

FIGURE 7 Effect of support length on turbine characteristics under steady flow condition (circular type). (a) Torque coefficient, (b) input coefficient.

Mean efficiencies for full-length airfoil shaped supports are shown in Fig. 8 together with the data of circular cross section support, where the maximum thickness of airfoil type support is 


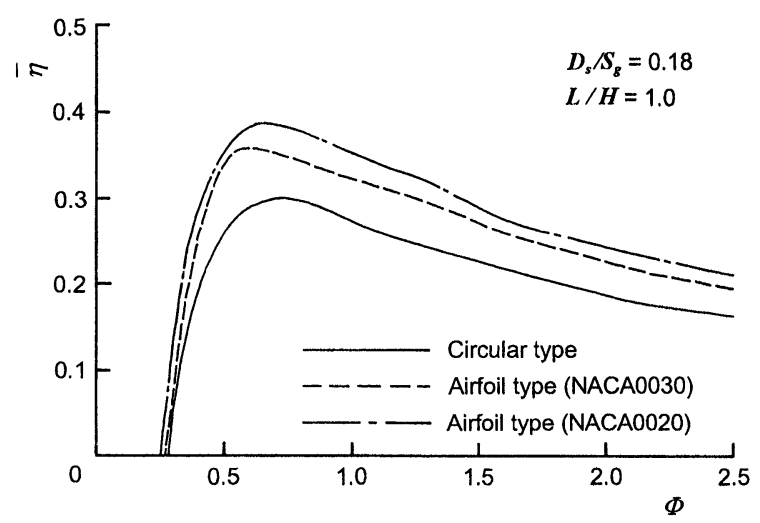

FIGURE 8 Effect of support shape on mean efficiency.

$5.5 \mathrm{~mm}$ that is the same as diameter of circular type support. From the figure, it is found that the efficiency for the case with airfoil type is higher than that for the case of circular type. This is because $C_{\mathrm{A}}$ of the case with airfoil type is lower in comparison with that of circular type as shown in Fig. 9(b). Moreover, for the case with airfoil type, the efficiency for NACA0020 (thickness-to-chord ratio: $20 \%$ ) is higher than that of NACA0030. This is because that torque coefficient is slightly better with more streamlining of the support as indicated by Fig. 9(a). However, the efficiency for the case with airfoil type is inferior to that for the case of sharp edge shown in Fig. 4.

\section{Starting Characteristics}

The starting characteristics of the turbine are evaluated by the variation of rotational speed from the rest point. Figure 10 shows a comparison of starting characteristics under sinusoidal flow condition without any load on the turbine. The results are given in the form of dimensionless angular velocity $\omega^{*}$ versus dimensionless time $t^{*}$. Here, $S, X_{\mathrm{I}}$ and $X_{\mathrm{L}}$ denote dimensionless frequency, dimensionless moment of inertia of the rotor and dimensionless loading torque, respectively (Inoue et al., 1986).

Figure 10(a) shows the effect of the support diameter on starting characteristics. The case of sharp edge is denoted by the dotted line for comparison. It is clear that the rotational speed
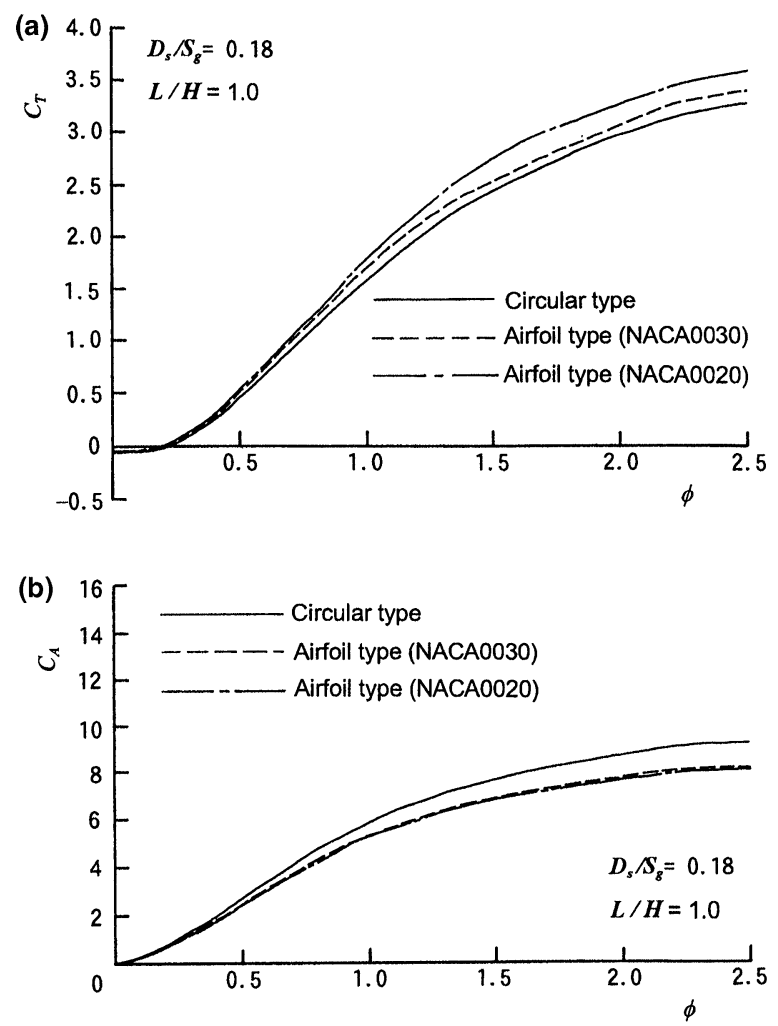

FIGURE 9 Effect of support shape on turbine characteristics under steady flow condition. (a) Torque coefficient, (b) input coefficient

for the case with support is slightly lower than the case without support although the starting characteristics does not depend on the diameter of support. This is because the flow coefficient at loading-free condition (i.e., $C_{\mathrm{T}}=0$ ) for the case with support is larger than for the case of sharp edge as shown in Fig. 5(a). The effect of the support length on the starting characteristics is shown in Fig. 10(b). The rotational speed decreases with the increase of $L / H$. Figure 10(c) shows the effect of the support shape on the starting characteristics. The figure shows that the rotational speed for the case with circular type is lower than for the case with airfoil type. This means that the use of circular type support is advantageous from a viewpoint of low rotating speed operation in comparison with that of airfoil type support. 
(a)

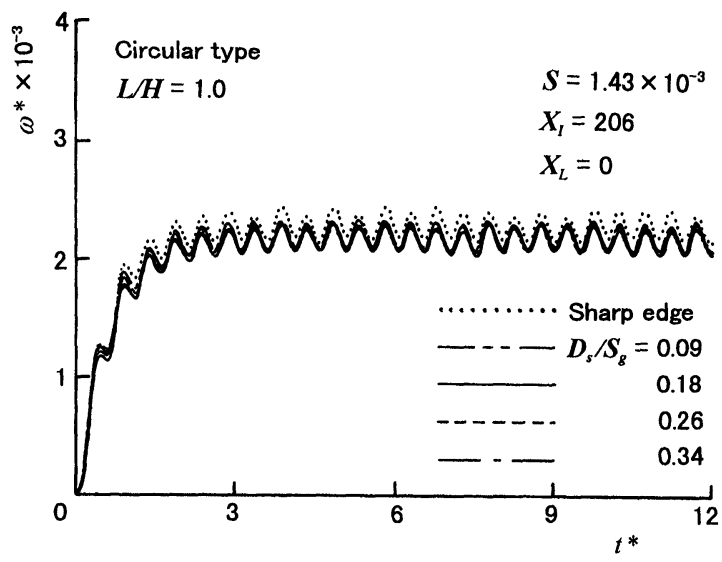

(b)
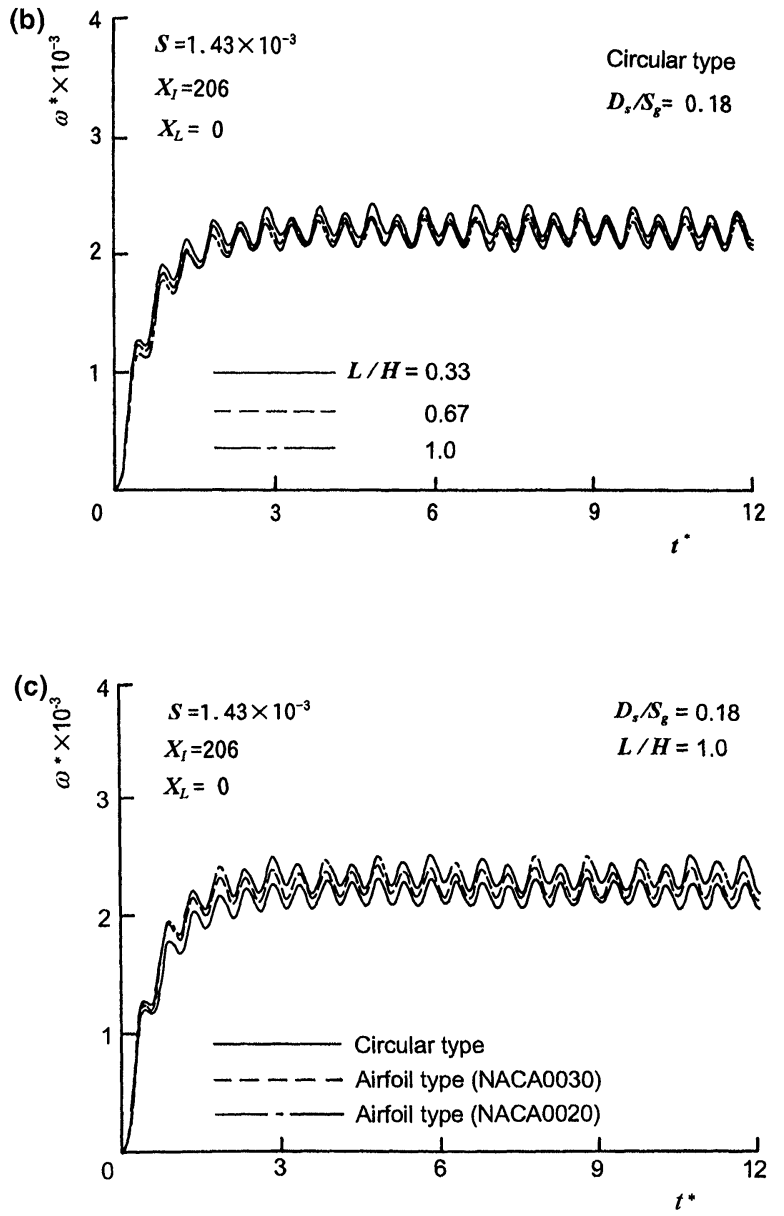

FIGURE 10 Starting characteristics. (a) Effect of support diameter, (b) effect of support length, (c) effect of support shape.

\section{CONCLUSIONS}

The experimental studies have been carried out to clarify the effect of guide vane support geometry on the performance of impulse turbine with self-pitchcontrolled guide vane. The conclusions obtained are summarized as follows.

(1) The presence of support causes the deterioration in turbine efficiency. This is due to the increase of input coefficient caused by support.

(2) The turbine efficiency over a wider range of flow coefficient $\Phi$ decreases with the increase of both the thickness $D_{\mathrm{s}} / S_{\mathrm{g}}$ and the length $L / H$ of the support.

(3) The running characteristics of the case with airfoil type is superior to that with circular type.

(4) The use of circular type support is advantageous from a viewpoint of low rotating speed operation in comparison with that of airfoil type support.

\section{NOMENCLATURE}

$b \quad$ rotor blade height

$C_{\mathrm{A}} \quad$ input coefficient

$C_{\mathrm{T}}$ torque coefficient

$D_{\mathrm{s}} \quad$ diameter of circular cross section of support

$f \quad$ frequency of wave

$H$ guide vane height

I moment of inertia of rotor

$l \quad$ chord length of rotor blade

$l_{\mathrm{g}} \quad$ chord length of guide vane

$L \quad$ support length

$Q \quad$ flow rate

$r_{\mathrm{R}} \quad$ mean radius

$S \quad$ dimensionless frequency $=f r_{\mathrm{R}} / V_{\mathrm{a}}$

$S_{\mathrm{g}} \quad$ guide vane space

$t$ time

$t^{*} \quad$ dimensionless time $=t f$

$T$ output torque 
$T_{\mathrm{L}} \quad$ loading torque

$U_{\mathrm{R}} \quad$ circumferential velocity of rotor

$v_{\mathrm{a}} \quad$ mean axial velocity

$V_{\mathrm{a}} \quad$ maximum value of $v_{\mathrm{a}}$

$X_{\mathrm{I}}$ dimensionless moment of inertia of rotor $=I /\left(\pi \rho r_{\mathrm{R}}^{5}\right)$

$X_{\mathrm{L}} \quad$ dimensionless loading torque $=T_{L} /\left(\pi \rho r_{\mathrm{R}}^{3} V_{\mathrm{a}}^{2}\right)$

$z \quad$ number of rotor blades

$\Delta p \quad$ total pressure drop between settling chamber and atmosphere

$\eta \quad$ turbine efficiency

$\bar{\eta} \quad$ mean efficiency

$\theta_{1} \quad$ nozzle setting angle of guide vane

$\theta_{2}$ diffuser setting angle of guide vane

$\rho \quad$ density of air

$\phi, \Phi$ flow coefficient

$\omega \quad$ angular velocity

$\omega^{*} \quad$ dimensionless angular velocity $=\omega / f$

\section{References}

Inoue, M., Kaneko, K., Setoguchi, T. and Raghunathan, S. (1986) Simulation of starting characteristics of the Wells turbine, AIAA/ASME 4th Fluid Mech., Plasma Dynamics Laser Conf., AIAA-86-1122.
Kaneko, K., Setoguchi, T. and Inoue, M. (1986) Performance of the Wells turbine in oscillating flow, Proc. Current Practices and New Tech. in Ocean Engineering (ASME), Vol. 2, pp. 447452.

Raghunathan, S. and Tan, C.P. (1982) Performance of the Wells turbine at starting, Journal of Energy, 6(6), 430-431.

Santhakumar, S., Jayashankar, Atmanand, M.A., Pathak, M.V., Ravindran, M.V., Setoguchi, T., Takao, M. and Kaneko, K. (1998) Performance of an impulse turbine based wave energy plant, Proc. 8th Int'l. Offshore and Polar Eng. Conf., Vol. 1, pp. 75-80.

Sarmento, A.J.N.A., Gato, L.M.C. and Falcao, A.F.deO. (1987) Wave-energy absorption by an OWC device blade-pitchcontrolled air turbine, Proc. 6th Int'l. Offshore Mech. and Arctic Eng. Symp., Vol. 2, pp. 465-473.

Setoguchi, T., Kaneko, K., Matsuki, E., Hamakawa, H. and Inoue, M. (1990) Some techniques to improve the performance of biplane Wells turbine for wave power generator, Proc. 1st Pac/Asia Offshore Mech. Symp., Vol. 1 , pp. 207-212.

Setoguchi, T., Kaneko, K., Maeda, H., Kim, T.W. and Inoue, M. (1991) Performance of impulse turbine with selfpitch-controlled guide vanes for wave power conversion, Proc. 1st Int'l. Offshore and Polar Eng. Conf., Vol. 1, pp. 544-549.

Setoguchi, T., Kaneko, K., Taniyama, H., Maeda, H. and Inoue, M. (1996) Impulse turbine with self-pitch-controlled guide vanes for wave power conversion: Guide vanes connected by links, Int'l. Journal of Offshore and Polar Eng., 6, 76-80. 


\section{ait \\ ENERGY MATERIALS}

M A N E Y publishing

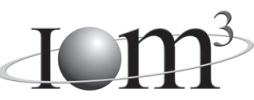

\section{Materials Science \& Engineering for Energy Systems}

Maney Publishing on behalf of the Institute of Materials, Minerals and Mining

The Institute of Materials, Minerals \& Mining

Economic and environmental factors are creating ever greater pressures for the efficient generation, transmission and use of energy. Materials developments are crucial to progress in all these areas: to innovation in design; to extending lifetime and maintenance intervals; and to successful operation in more demanding environments. Drawing together the broad community with interests in these areas, Energy Materials addresses materials needs in future energy generation, transmission, utilisation, conservation and storage. The journal covers thermal generation and gas turbines; renewable power (wind, wave, tidal, hydro, solar and geothermal); fuel cells (low and high temperature); materials issues relevant to biomass and biotechnology; nuclear power generation (fission and fusion); hydrogen generation and storage in the context of the 'hydrogen economy'; and the transmission and storage of the energy produced.

As well as publishing high-quality peer-reviewed research, Energy Materials promotes discussion of issues common to all sectors, through commissioned reviews and commentaries. The journal includes coverage of energy economics and policy, and broader social issues, since the political and legislative context influence research and investment decisions.

\section{CALL FOR PAPERS}

Contributions to the journal should be submitted online at http://ema.edmgr.com

To view the Notes for Contributors please visit: www.maney.co.uk/journals/notes/ema

Upon publication in 2006, this journal will be available via the Ingenta Connect journals service. To view free sample content online visit: www.ingentaconnect.com/content/maney

For further information please contact:

Maney Publishing UK

Tel: +44 (0)113 2497481 Fax: +44 (0)1132486983 Email: subscriptions@maney.co.uk

or

Maney Publishing North America

Tel (toll free): 8662975154 Fax: 6173546875 Email: maney@maneyusa.com

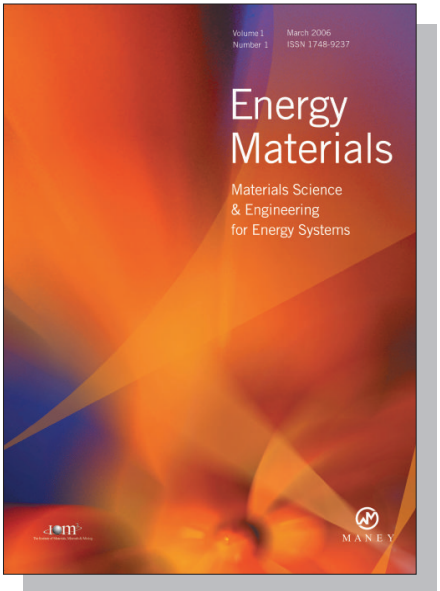

EDITORS

Dr Fujio Abe

NIMS, Japan

Dr John Hald, IPL-MPT, Technical University of Denmark, Denmark

Dr R Viswanathan, EPRI, USA

\section{SUBSCRIPTION INFORMATION}

Volume 1 (2006), 4 issues per year

Print ISSN: 1748-9237 Online ISSN: 1748-9245

Individual rate: $£ 76.00 / U S \$ 141.00$

Institutional rate: $£ 235.00 /$ US $\$ 435.00$

Online-only institutional rate: $£ 199.00 / U S \$ 367.00$

For special $\mathrm{IOM}^{3}$ member rates please email

subscriptions@maney.co.uk

\section{For further information or to subscribe online please visit www.maney.co.uk}



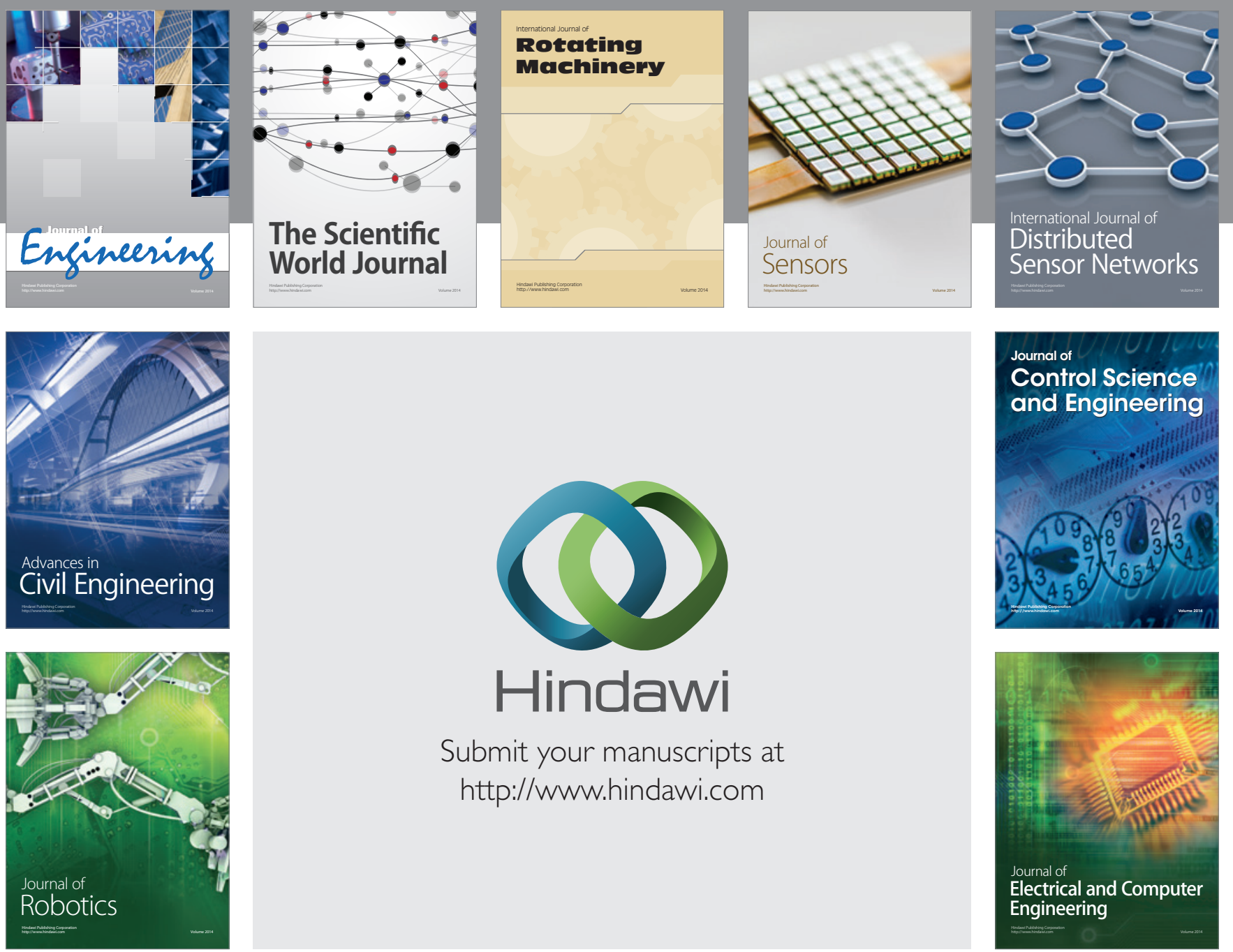

Submit your manuscripts at

http://www.hindawi.com
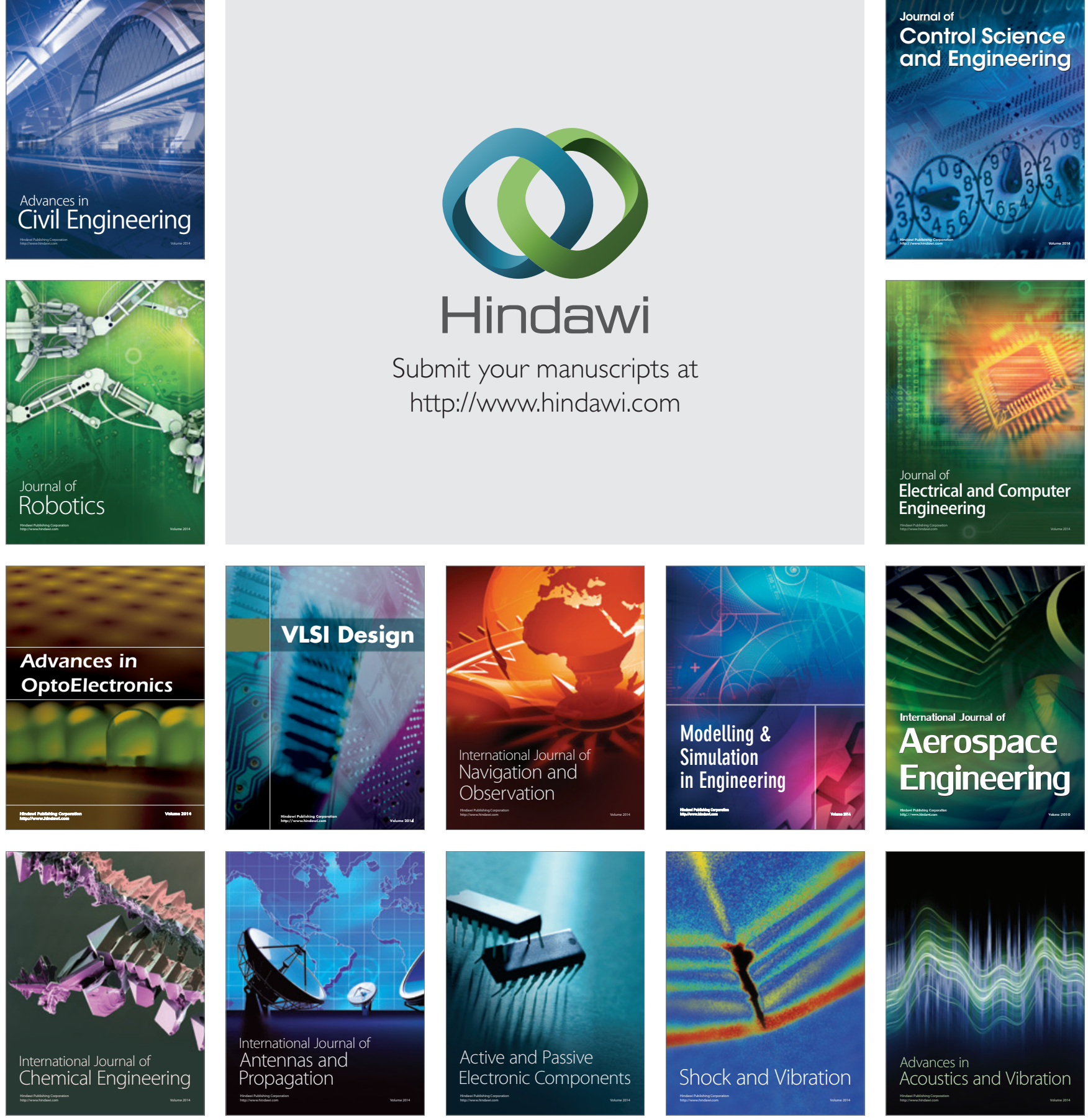